\title{
RECENT SEA LEVEL CHANGES IN THE BLACK SEA FROM SATELLITE GRAVITY AND ALTIMETER MESUREMENTS
}

\author{
N. B. Avsar ${ }^{1, *}$, S. Jin ${ }^{1,2}$, S. H. Kutoglu ${ }^{1}$ \\ ${ }^{1}$ Dept. of Geomatics Engineering, Bulent Ecevit University, 67100 Incivez Zonguldak, Turkey - nb_avsar@beun.edu.tr, \\ kutogluh@hotmail.com \\ ${ }^{2}$ Shanghai Astronomical Observatory, Chinese Academy of Sciences, 200030 Shanghai, China - sgjin@ shao.ac.cn
}

KEY WORDS: Black Sea, Sea Level Change, Altimetry, GRACE

\begin{abstract}
:
Sea level rise causes devastating effects on coastal habitats. For example, coastal erosion and saltwater intrusion are major threats for the Black Sea coasts. So, determining sea level changes in the Black Sea is important in terms of coastal risk assessment and coastal planning. In this study, present-day sea level change in the Black Sea is estimated from satellite altimetry and gravity measurements. Altimetry data demonstrate that the Black Sea level has risen at an average rate of $2.5 \pm 0.5 \mathrm{~mm} /$ year from January 1993 to May 2017. During this period, inter-annual variability of the non-seasonal sea level change is quite strong. Furthermore, mass contribution to this change for the period 2002-2017 has been detected as $2.3 \pm 1.0 \mathrm{~mm} / \mathrm{year}$ from the Gravity Recovery And Climate Experiment (GRACE) mascon solutions.
\end{abstract}

\section{INTRODUCTION}

Recently sea level changes due to global warming have strong effects on coast environments and living conditions, e.g. in the Black Sea (Avsar et al., 2015). The Black Sea, located approximately between latitudes of $41^{\circ}$ to $46^{\circ} \mathrm{N}$ and longitudes of $28^{\circ}$ to $41.5^{\circ} \mathrm{E}$, is one of the farthest seas among the seas of the Atlantic Ocean basin. It has rather limited water exchange with the Mediterranean Sea through the Turkish Straits System (the Bosphorus Strait - the Sea of Marmara - the Dardanelles Strait). Unlike the Mediterranean Sea (concentration basin), the Black Sea is an estuarine basin that is due to major European rivers discharge (Jaoshvili, 2002; Stanev et al., 2000). According to Özsoy and Ünlüata (1997), the excess of river inflow $\left(\sim 350 \mathrm{~km}^{3} /\right.$ year) and precipitation $\left(\sim 300 \mathrm{~km}^{3} /\right.$ year) over evaporation $\left(\sim 350 \mathrm{~km}^{3} /\right.$ year $)$ is balanced by the net outflow $\left(\sim 300 \mathrm{~km}^{3} /\right.$ year) through the Bosphorus Strait (Volkov and Landerer, 2015). Therefore, the forcing of sea level in the Black Sea is dominated by the basin's freshwater budget and the water exchange through the Bosphorus Strait as well as depthintegrated changes in the seawater density.

In order to predict regional sea level change accurately, reliable observations revealing sea level forcing mechanisms should be provided. In this study, we present an analysis of present-day sea level changes in the Black Sea using satellite altimetry and gravity data.

\section{LONG-TERM SEA LEVEL CHANGES IN THE BLACK SEA}

At seasonal timescale, the variations in river discharges, precipitation, evaporation and outflow of water through the straits induce oscillations in the Black Sea level with amplitudes of $\sim 10 \mathrm{~cm}$ (Korotaev et al., 2001). However, considering long- term variability of the sea level, both tide-gauge and altimetry observations show that sea level trends in the Black Sea varies over time. From the beginning of tide gauge observations of the Black Sea (in 1875) to the first decade of the 21 st century, an increase in the sea level, on the average, was generally observed, with alternating period of rise and fall (Ginzbug et al., 2011; 2013). During the period 1875-1922, the Black Sea level was relatively stable with a slight tendency to decrease; from 1920 to 1985 , there was an increase at a rate of $1.8 \mathrm{~mm} /$ year. Based on satellite altimetry measurements over 1993-1998, Cazenave et al. (2002) reported that the Black Sea level rose at a high rate of around $27 \mathrm{~mm} /$ year. According to Avsar et al. (2015), the rate of rise was $3.2 \mathrm{~mm} / \mathrm{year}$ with analysis of altimetry data between January 1993 and December 2014. Changes in the budget of water (water balance) are considering as the main reason for the basin-averaged sea level changes in the Black Sea (Ginzburg et al, 2013; Kubryakov et al., 2017; Stanev et al., 2000; Volkov and Landerer, 2015; Yildiz et al., 2011). For example, Ginzburg et al. (2013) concluded that the sea level change in 1993-2002 was well correlated with variability of the Danube discharge.

\subsection{Time Evolution of Sea Level in the Black Sea from Satellite Altimetry}

Weekly mean sea level time series for the Black Sea from January 1993 to May 2017 have been provided from the French Archiving, Validation and Interpretation of the Satellite Oceanographic Data (AVISO; http://www.aviso. altimetry.fr/en/ data.html). This product, computed with Topex/Poseidon and Jason-1\&2\&3 altimetry missions, are 2-month filtered data. In order to compute trend, and filter seasonal (semi-annual and annual) signals, we adjust by least squares fitting the time series to the following expression (Avsar et al., 2016):

\footnotetext{
* Corresponding author
} 
$M(t)=a+b t+\sum_{k=1}^{2} A_{k} \sin \left(\omega_{k}\left(t-t_{0}\right)+\phi_{k}\right)+\varepsilon(t)$

where

$$
\begin{aligned}
& M(t)=\text { sea level time series, } \\
& t=\text { time, } t_{0}=1 \text { January } 1993, \\
& a=\text { constant }, b=\text { linear trend, } \\
& k=1 \text { annual variation, } \\
& k=2 \text { semi-annual variation, } \\
& A=\text { amplitude, } \\
& \omega=\text { angular frequency, } \\
& \phi_{k}=\text { phase, } \\
& \varepsilon(t)=\text { unmodelled residual term. }
\end{aligned}
$$

It has been found that over the period 1993-2017 the Black Sea level has risen at a rate of about $2.5 \pm 0.5 \mathrm{~mm} /$ year. To show up inter-annual variability of the Black Sea level, the residual sea level after removing the seasonal signal is presented in Figure 1.

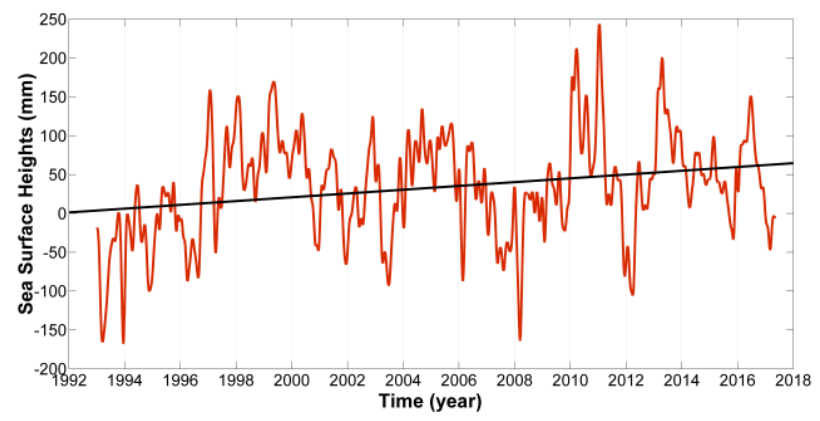

Figure 1. Sea level time series in the Black Sea from the satellite altimetry data over 1993-2017 and its linear fit (Seasonal signals removed)

The satellite altimetry observations from 1993 to 2017 revealed the standard deviation of $\sim 7 \mathrm{~cm}$ for sea level heights in the Black Sea. The Black Sea level in 2010 was about $20 \mathrm{~cm}$ above the 1993 average, and this was the highest annual average in the satellite record (1993-present). During this period, the recordhigh sea level observed in March 2010, January 2011, and April 2013.

\subsection{Water mass changes in the Black Sea from GRACE}

Total sea level variation is the sum of steric (the signal caused by temperature and salinity fluctuations) and mass-induced (the signal caused by addition/subtraction of water to/from water column) variations (Chambers et al., 2004; Garcia-Garcia et al., 2010). Satellite altimetry measures the total sea level variation. Steric sea level variations can be determined through temperature and salinity profiles from in-situ measurements or ocean assimilation models. The mass-induced sea level variations can be estimated from its time-variable gravity signals. The Gravity Recovery And Climate Experiment (GRACE) satellite mission, launched in 2002, enables to directly observe changes in water mass. Monthly estimates of the Earth's gravity field from GRACE are used to construct a time series of water mass variations (Chambers et al., 2004; Feng et al., 2013; Garcia-Garcia et al., 2010; Yildiz et al., 2011; Zhou et al., 2016).

In this study, to estimate water mass variations in the Black Sea, we use GRACE RL05 Mascon solutions from the Center for Space Research (CSR) - The University of Texas at Austin, spanning from April 2002 to June 2017 (Save et al. 2016). The GRACE data are monthly mass grids corresponding changes in equivalent water thickness relative to a time-mean baseline. Mass Concentration blocks (mascons) are essentially another form of gravity field basis functions (including spherical harmonics) to which GRACE's inter-satellite ranging observations are fit. Each mascon has a specific known geophysical location. These data are represented on a 0.5 degree lon-lat grid, but they represent the equal-area geodesic grid of size $1^{\circ} \times 1^{\circ}$ at the equator, which is the current native resolution of CSR RL05 mascon solutions. Mascon solutions typically do not need to be destriped or smoothed unlike spherical harmonic coefficients. Moreover, they allow a better separation of land and ocean areas. Nevertheless, here, we consider an ocean mask in order to minimize leakage along the coastline (http://www2.csr.utexas.edu/grace/RL05_mascons.html). The data also have a Glacial Isostatic Adjustment (GIA) correction.

For this study, we cut out the Black Sea data from the global dataset, and obtain the basin-averaged time series of equivalent water thickness. For the analysis, the 20 missing solutions in the GRACE data between April 2002 and June 2017 have been interpolated. Then, the mass-induced contribution to sea level change in the Black Sea during the period of 2002-2017 is derived from the GRACE mascon solutions using Equation (1). Accordingly, the result shows a rate of the non-seasonal seawater mass change of about $2.3 \pm 1.0 \mathrm{~mm} / \mathrm{yr}$ over the last 15 years.

Figure 2 demonstrates the monthly time series of the Black Sea level from April 2002 to December 2014 from satellite altimetry (sea level anomalies) and satellite gravity (equivalent water thickness). For this period, while the sea level rise from satellite altimetry is about $3.3 \pm 1.5 \mathrm{~mm} / \mathrm{yr}$, the GRACE observations indicate sea water mass variations at a rate of $1.6 \pm 1.4 \mathrm{~mm} / \mathrm{yr}$. According to Figure 2, both observations exhibit similar fluctuations especially in some time periods. For example, the mass-induced sea level changes may be major factor for the increase of sea level in the Black Sea in the early 2010s. Our results support the idea by suggested Volkov and Landerer (2015): the observed large fluctuations of sea level in 2011 and 2013 have been driven the freshwater fluxes in the Black Sea.

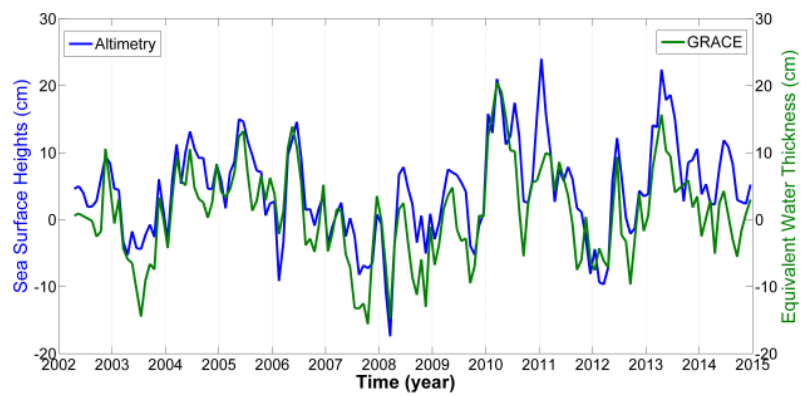

Figure 2. The variability of the Black Sea level over 2002-2014 from satellite altimetry (total) and gravity data (mass-induced)

\section{CONCLUSIONS}

The aim of the present study was to investigate long-term total sea level changes in the Black Sea by considering the contribution of the water mass changes. The basin-mean sea 
level rise from January 1993 to May 2017 is about $2.5 \mathrm{~mm} /$ year. However, the sea level trends in the Black Sea are not constant over time. The analysis of monthly satellite altimetry and gravity time series between April 2002 and December 2014 demonstrates a rising trend at a mean rate of $\sim 3.3 \mathrm{~mm} /$ year, and $\sim 1,6 \mathrm{~mm} /$ year for total and mass-induced sea level changes in the Black Sea, respectively. In this sense, steric changes can be expected to contribute to the sea level rise in this basin. Nevertheless, we confirm that the non-seasonal sea level budget in the Black Sea is dominated by water mass changes.

This study demonstrated that GRACE data can be used to estimate non-steric sea level changes in the Black Sea. For the period of 2002-2017, the GRACE-derived water mass change shows a rising trend at a rate of about $2.3 \mathrm{~mm} /$ year. This change should be compared with steric-corrected altimetry observations for more accurate evaluation of the contributions to sea level change. It is important to identify the contributions at adapting to potential impacts of the sea level rise.

\section{ACKNOWLEDGEMENTS}

The authors are grateful to the organizations that provided the data, including the Centre National d'Etudes Spatiales - CNES AVISO, and The University of Texas at Austin Center for Space Research - The UT CSR. The authors would also like to thank Dr. Bihter Erol from the Istanbul Technical University, and Dr. E. Ozgur Avsar from the Canakkale Onsekiz Mart University for their valuable contributions to this study.

\section{REFERENCES}

Avsar, N.B., Kutoglu, S.H., Erol, B. and Jin, S.G., 2015. Coastal risk analysis of the Black Sea under the sea level rise. FIG Working Week 2015, From the wisdom of the ages to the challenges of the modern world, 17-21 May, Sofia, Bulgaria.

Avsar, N.B., Jin, S.G., Kutoglu, H. and Gurbuz, G., 2016. Sea level change along the Black Sea coast from satellite altimetry, tide gauge and GPS observations. Geod. Geodyn., 7(1), pp. 5055 .

Cazenave, A., Bonnefond, P.F., Mercier, F., Dominh, K. and Toumazou, V., 2002. Sea level variations in the Mediterranean Sea and Black Sea from satellite altimetry and tide gauges. Global Planet. Change, 34(1-2), pp. 59-86.

Chambers, D.P., Wahr, J. and Nerem, R.S., 2004. Preliminary observations of global ocean mass variations with GRACE. Geophys. Res. Lett., 31, L13310.

Feng, G.P., Jin, S.G. and Zhang, T.Y., 2013. Coastal sea level changes in the Europe from GPS, Tide Gauge, Satellite Altimetry and GRACE, 1993-2011. Adv. Space Res., 51(6), pp. $1019-1028$

Garcia-Garcia, D., Chao, B.F., Boy, J.-P., 2010. Steric and mass-induced sea level variations in the Mediterranean Sea revisited. J. Geophys. Res., 115, C12016.

Ginzburg, A.I., Kostianoy, A.G., Sheremet, N.A. and Lebedev, S.A., 2011. Satellite Altimetry

Applications in the Black Sea. In: Coastal Altimetry (Vignudelli, S., Kostianoy, A.G., Cipollini, P., and Benveniste, J., Eds.), Springer-Verlag Berlin Heidelberg, pp 367-387.
Ginzburg, A.I., Lebedev, S.A., Kostianoy, A.G. and Sheremet, N.A., 2013. Interannual variability of the Black Sea level basing on the radar altimetry. In: Proceedings of the 20 years of Progress in Radar Altimetry (Ouwehand, L., Ed.), Venice, Italy (ESA SP-710, February 2013).

Jaoshvili, S., 2002. The rivers of the Black Sea. EEA Technical Report 71, European Environmental Agency, 58 pp https://www.eea.europa.eu/publications/technical_report_2002_ 71

Korotaev, G.K., Saenko, O.A. and Koblinsky, C.J., 2001. Satellite altimetry observations of the Black Sea level. $J$. Geophys. Res., 106(C1), pp. 917-933.

Kubryakov, A.A., Stanichny, S.V. and Volkov, D.L., 2017. Quantifying the impact of basin dynamics on the regional sea level rise in the Black Sea. Ocean Sci., 13, pp. 443-452.

Özsoy, E., and Ünlüata, Ü., 1997. Oceanography of the Black Sea: a review of some recent results. Earth Sci. Rev., 42(4), pp. 231-272.

Save, H., Bettadpur, S. and Tapley, B.D., 2016. High-resolution CSR GRACE RL05 mascons. J. Geophys. Res. Solid Earth, 121(10), pp. 7547-7569.

Stanev, E.V, Le Traon, P.-Y., and Peneva, E.L., 2000. Sea level variations and their dependency on meteorological and hydrological forcing: Analysis of altimeter and surface data for the Black Sea. J. Geophys. Res., 105(C7), pp. 17203-17216.

Volkov, D.L. and Landerer, F.W., 2015. Internal and external forcing of sea level variability in the Black Sea, Clim. Dyn., 45(9-10), pp. 2633-2646.

Yildiz, H., Andersen, O.B., Simav, M., Kilicoglu, A. and Lenk, O., 2011. Black sea annual and inter-annual water mass variations from space. J. Geodesy, 85, pp. 119-127.

Zhou, Y., Jin, S.G., Tenzer, R. and Feng, J., 2016. Water storage variations in the Poyang Lake basin estimated from GRACE and Satellite Altimetry. Geod. Geodyn., 7(2), pp. 108116. 